\title{
Performance validation of sodium- ion batteries using an ionic liquid electrolyte
}

\section{$\operatorname{AUTHOR}(S):$}

Fukunaga, Atsushi; Nohira, Toshiyuki; Hagiwara, Rika; Numata, Koma; Itani, Eiko; Sakai, Shoichiro; Nitta, Koji

\section{CITATION:}

Fukunaga, Atsushi ...[et al]. Performance validation of sodium-ion batteries using an ionic liquid electrolyte. Journal of Applied Electrochemistry 2016, 46(4): 487-496

\section{ISSUE DATE:}

2016-04

URL:

http://hdl.handle.net/2433/230385

\section{RIGHT:}

This is a post-peer-review, pre-copyedit version of an article published in 'Journal of Applied Electrochemistry'. The final authenticated version is available online at: https://doi.org/10.1007/s10800-016-0940-6; The full-text file will be made open to the public on 1 April 2017 in accordance with publisher's 'Terms and Conditions for Self-Archiving'.; This is not the published version. Please cite only the published version.; この論文は出版社版でありません。引用の際には出版社 版をご確認ご利用ください。 


\section{Performance validation of sodium-ion batteries using an ionic liquid electrolyte}

Atsushi Fukunaga ${ }^{\mathrm{a}, \mathrm{b}}$, Toshiyuki Nohira ${ }^{\mathrm{c}, *}$, Rika Hagiwara ${ }^{\mathrm{a}, *}$, Koma Numata ${ }^{\mathrm{b}}$, Eiko Itani ${ }^{\mathrm{b}}$, Shoichiro Sakai $^{\mathrm{b}}$, Koji Nitta $^{\mathrm{b}}$

a. Graduate School of Energy Science, Kyoto University, Yoshida-honmachi, Sakyo-ku, Kyoto 606-8501, Japan.

b. Sumitomo Electric Industries Ltd., 1-1-3 Shimaya, Konohana-ku, Osaka 554-0024, Japan.

c. Institute of Advanced Energy, Kyoto University, Gokasho, Uji, Kyoto 611-0011, Japan.

*Corresponding authors: Tel.: +81-774-38-3500; Fax: +81-774-38-3499 (T. Nohira), Tel.:

+81-75-753-5822; Fax: +81-75-753-5906 (R. Hagiwara). E-mail addresses:

nohira.toshiyuki.8r@kyoto-u.ac.jp, hagiwara@energy.kyoto-u.ac.jp. 


\begin{abstract}
Charge-discharge properties of sodium-ion batteries using the $\mathrm{Na}[\mathrm{FSA}]-\left[\mathrm{C}_{3} \mathrm{C}_{1}\right.$ pyrr] [FSA] (FSA: bis(fluorosulfonyl)amide, $\mathrm{C}_{3} \mathrm{C}_{1}$ pyrr: $N$-methyl-N-propylpyrrolidinium) ionic liquid were investigated over a temperature range of $273-363 \mathrm{~K} . \mathrm{NaCrO}_{2}$ and hard carbon (HC) were used as positive electrode and negative electrode active materials, respectively, and their fundamental charge-discharge characteristics were examined with coin-type half-cells. A $1.5 \mathrm{mAh}$ coin-type full cell composed of $\mathrm{HC} / \mathrm{NaCrO}_{2}$ showed excellent cycle properties, maintaining $90 \%$ of its initial capacity after 1000 cycles at 333 and $363 \mathrm{~K}$. The $1.5 \mathrm{mAh}$ full cell also exhibited a high charge-discharge energy efficiency of $97.5 \%$ at $363 \mathrm{~K}$ and $\mathrm{C} / 5$ rate. A large-sized prismatic $\mathrm{HC} / \mathrm{NaCrO}_{2}$ full cell with a capacity of 27 Ah was fabricated by a mass production process, and its performance was confirmed to be comparable with that of the $1.5 \mathrm{mAh}$ coin-type cell.
\end{abstract}

Key words: sodium secondary battery; ionic liquid; bis(fluorosulfonyl)amide; $\mathrm{NaCrO}_{2}$ positive electrode; hard carbon negative electrode; full cell performance 


\section{Introduction}

The demand for secondary batteries for energy-storage devices has recently experienced significant growth for use in important applications such as load leveling, emergency power supply devices, and smart grids [1-2]. As high-performance secondary batteries, lithium-ion batteries (LIBs) are popular not only for mobile applications but also for electric vehicle and household uses [3-4]. However, difficulties in locating and extracting material resources for LIBs are anticipated in the near future, because such devices employ minor metals like cobalt and nickel [5-15]. Even for lithium, a stable supply seems to be problematic over the long term because high-quality lithium resources are unevenly distributed in the earth's crust, occurring mainly in China and South America [16-18]. Thus, the research and development of secondary batteries using only easily available raw materials such as sodium has become an active field of investigation. In support of this fact, the number of reports on sodium secondary batteries has risen rapidly in the past 2-3 years [5-15]. Sodium, which can be easily obtained from seawater or the earth's crust, possesses a reasonably negative standard redox potential of $-2.714 \mathrm{~V}$ vs. the standard hydrogen electrode (SHE). Furthermore, many advanced technologies designed for use in LIBs are expected to be applicable in sodium secondary batteries [5-15].

The development of sodium secondary batteries has a long history. Batteries using $\beta "$-alumina electrolyte have been studied for many years [19-24], and $\mathrm{Na} / \mathrm{S}$ and $\mathrm{Na} / \mathrm{NiCl}_{2}$ batteries are currently in practical use as large-scale energy-storage devices for mega solar power plants and wind farms. However, these batteries have less-than-ideal operating conditions for such industrial applications. The $\beta^{\prime \prime}-$ alumina electrolyte needs an operating temperature of approximately $573 \mathrm{~K}$ to raise its conductivity. Furthermore, $\mathrm{Na} / \mathrm{S}$ and $\mathrm{Na} / \mathrm{NiCl}_{2}$ batteries require liquid sodium metal, which is an extremely hazardous material. Thus, storage and installation of $\mathrm{Na} / \mathrm{S}$ and $\mathrm{Na} / \mathrm{NiCl}_{2}$ batteries are restricted because of their large size and the regulations placed on the use of sodium metal.

At the same time, reports on sodium secondary batteries using organic electrolytes have recently increased [25-27]. These reports highlight promising advantages of these batteries, such as energy density, cost, and material abundance. However, the use of organic solvents in batteries, similar to conventional LIBs, requires safety considerations, because an accident involving such batteries can be destructive (and potentially lethal) for large-scale batteries. Moreover, the required organic solvents cannot be used at intermediate or high temperatures because of their high volatility and the low stability 
of solid-electrolyte interphases (SEIs) on negative electrodes. Accordingly, large-scale and assembled sodium secondary batteries using organic solvents must be equipped with cooling systems, similar to LIBs, in order to be used safely.

The development of safe and high-performance electrolytes is badly needed in order to address the drawbacks listed in the previous paragraph. We have developed several ionic liquids for sodium secondary battery electrolytes that have high thermal stabilities, high ionic conductivities, and wide electrochemical windows [28-31]. We have demonstrated their actual operation using $\mathrm{Na} / \mathrm{Na}[\mathrm{TFSA}]-\mathrm{Cs}[\mathrm{TFSA}] / \mathrm{NaCrO}_{2}$ (TFSA: bis(trifluoromethylsulfonyl)amide; operating temperature: 423 K) [32], $\mathrm{Na} / \mathrm{Na}[\mathrm{FSA}]-\mathrm{K}[\mathrm{FSA}] / \mathrm{NaCrO}_{2}$ (FSA: bis(fluorosulfonyl)amide; operating temperature: $353 \mathrm{~K}$ ) [33], and $\mathrm{Na} / \mathrm{Na}[\mathrm{FSA}]-\left[\mathrm{C}_{3} \mathrm{C}_{1}\right.$ pyrr][FSA $] / \mathrm{NaCrO}_{2} \quad\left(\mathrm{C}_{3} \mathrm{C}_{1}\right.$ pyrr: $\quad N$-methyl- $N$-propylpyrrolidinium, operating temperature: $253-353 \mathrm{~K}$ ) [34]. We have also confirmed excellent cycle performances, rate capabilities, and wide operating temperatures for batteries using these ionic liquids as the electrolyte medium and a $\mathrm{NaCrO}_{2}$ positive electrode. Recently, Xia et al. reported the stabilities of deintercalated $\mathrm{Na}_{0.5} \mathrm{CrO}_{2}$ (fully charged state) in nonaqueous solvents [35]. Xia reported that $\mathrm{NaCrO}_{2}$ is the best active material for the operation of sodium secondary batteries over a wide temperature range.

In previous studies, however, sodium metal was used as a negative electrode. Although dendrite deposition of sodium metal is suppressed by operating at a temperature close to the melting point of sodium (371 K) [34], it is difficult to completely prevent dendrite deposition, especially at lower operating temperatures. Referring to the reports on hard carbon (HC) by Komaba et al. [36-38], we also investigated $\mathrm{HC}$ negative electrodes [39] to avoid the use of sodium metal negative electrodes. Unfortunately, when the $\mathrm{Na}[\mathrm{FSA}]-\mathrm{K}[\mathrm{FSA}]$ ionic liquid was used, $\mathrm{HC}$ irreversibly reacted with $\mathrm{K}^{+}$cations during the charge-discharge test. However, good reversibility and rate capability were obtained by using the $\mathrm{Na}[\mathrm{FSA}]-\left[\mathrm{C}_{3} \mathrm{C}_{1}\right.$ pyrr][FSA] ionic liquid [39].

Much research has been conducted on sodium secondary batteries using half-cells, especially coin-type half-cells. Some of the work using half-cells reported the results of long-term cycle life of batteries. However, investigations on long-term cycle life should also be verified by using full cells. Unfortunately, few studies have been conducted using "full cells." Although full cell performance is predictable from the results of positive and negative electrode half-cell tests, actual verification using full cells is imperative for the practical applications of sodium secondary batteries. Ideally, the verification 
should also include the scaling up of full cells, because the most expected application of such cells is in large-size batteries. In this study, we first investigate the fundamental charge-discharge characteristics of $\mathrm{NaCrO}_{2}$ positive electrodes and $\mathrm{HC}$ negative electrodes using $\mathrm{Na}[\mathrm{FSA}]-\left[\mathrm{C}_{3} \mathrm{C}_{1}\right.$ pyrr $][\mathrm{FSA}]$ ionic liquids and coin-type half-cells at 333 and $363 \mathrm{~K}$. Furthermore, we examine, for the first time, the detailed full cell performance, including the long-term cycle life of a $1.5 \mathrm{mAh} \mathrm{HC} / \mathrm{NaCrO}_{2}$ cell using a coin-type cell over the temperature range of 273-363 K. Finally, we fabricate a large-sized prismatic full cell with a capacity of $27 \mathrm{Ah}$ and compare the performance with that of a coin-type cell.

\section{Experimental}

$\mathrm{Na}$ [FSA] (Mitsubishi Materials Electronic Chemicals Co., Ltd., Japan, >99.0\%) and $\left[\mathrm{C}_{3} \mathrm{C}_{1}\right.$ pyrr] $[\mathrm{FSA}]$ (Kanto Chemical Co., Inc. Japan, >99.0\%) were dried under vacuum at $333 \mathrm{~K}$ for $24 \mathrm{~h}$. The $\mathrm{Na}[\mathrm{FSA}]-\left[\mathrm{C}_{3} \mathrm{C}_{1}\right.$ pyrr][FSA] ionic liquid $\left(\mathrm{Na}[\mathrm{FSA}]:\left[\mathrm{C}_{3} \mathrm{C}_{1}\right.\right.$ pyrr $\left.][\mathrm{FSA}]=20: 80 \mathrm{~mol} \%\right)$ was prepared by mixing the salts under magnetic stirring. Inductively coupled plasma atomic emission spectroscopy (ICP-AES) and ion chromatography analysis showed that impurities in the electrolytes, such as metallic cations or halide anions, were less than $10 \mathrm{ppm}$. The electrochemical windows for $\mathrm{Na}[\mathrm{FSA}]-\left[\mathrm{C}_{3} \mathrm{C}_{1}\right.$ pyrr][FSA] systems have been previously measured to be $5.2 \mathrm{~V}$ at $353 \mathrm{~K}$ [34]. The water content of the electrolyte was determined to be less than $10 \mathrm{ppm}$ by the Karl Fischer titration method.

The positive electrode active material, $\mathrm{NaCrO}_{2}$, was prepared using a solid phase method. Equimolar amounts of $\mathrm{Na}_{2} \mathrm{CO}_{3}$ and $\mathrm{Cr}_{2} \mathrm{O}_{3}$ were mixed and then baked at $1123 \mathrm{~K}$ for $7 \mathrm{~h}$ under Ar flow. Figure 1 shows an XRD pattern of the obtained sample, confirming that the sample is $\mathrm{NaCrO}_{2}$ with no impurity. $\mathrm{NaCrO}_{2}$ thus prepared was well mixed with acetylene black (Denka Black, purity >99.99\%) and PVdF (Kureha) in $N$-methyl-2-pyrrolidone (Kishida Chemical Co., Ltd., >99.5\%) at a weight ratio of 85/10/5 using a dispersion mixer. The obtained slurry was then coated onto an aluminum foil current collector and pressed by a roller press. The loading weight was $13.5\left(\mathrm{mg}-\mathrm{NaCrO}_{2}\right) \mathrm{cm}^{-2}$ (ca. $1.7 \mathrm{mAh}$ in theoretical capacity $\left.125 \mathrm{mAh}\left(\mathrm{g}-\mathrm{NaCrO}_{2}\right)^{-1}\right)$. The negative electrode active material, $\mathrm{HC}$, was used as purchased (CARBOTRON P, Kureha Battery Materials Japan Co., Ltd.). HC and the polyamide-imide binder were mixed in $N$-methyl-2-pyrrolidone (Kishida Chemical Co., Ltd., >99.5\%) at a weight ratio of 96/4 using a dispersion mixer. The obtained slurry was coated onto a current collector and pressed by a roller press. The loading weight was $5.2(\mathrm{mg}-\mathrm{HC}) \mathrm{cm}^{-2}$. 
Charge-discharge properties of $\mathrm{Na} / \mathrm{NaCrO}_{2}$ and $\mathrm{Na} / \mathrm{HC}$ half-cells, and $\mathrm{HC} / \mathrm{NaCrO}_{2}$ full cell were measured with a 2032-type coin cell. A sodium foil (Aldrich, >99.9\%) was used as the negative electrode for $\mathrm{Na} / \mathrm{NaCrO}_{2}$ and $\mathrm{Na} / \mathrm{HC}$ half-cells. A microporous membrane (NPS050, Nippon Sheet Glass Co., Ltd., thickness: $50 \mu \mathrm{m}$ ) was used as the separator. Charge-discharge tests were conducted at a constant current rate by a computer-controlled charge-discharge unit (ABE 1024-05R1, Electrofield Corp). Current rate and cut-off voltages are shown in Table 1. Temperature of the cell was maintained at 273-363 K by a thermostatic oven during the charge-discharge tests.

In addition to a coin-type full cell, a $27 \mathrm{Ah}$ prismatic $\mathrm{HC} / \mathrm{NaCrO}_{2}$ full cell was fabricated using a mass production process. Figure 2 shows the appearance of the fabricated $27 \mathrm{Ah}$ cell. Positive electrodes, negative electrodes, and separators were the same as those used in the coin-type cell. Positive and negative electrode active materials were coated on both sides of the Al foil current collector. A bundle of electrodes and separators electrically connected in parallel via lead tabs. $\mathrm{Na}[\mathrm{FSA}]-\left[\mathrm{C}_{3} \mathrm{C}_{1}\right.$ pyrr] $[\mathrm{FSA}]$ electrolyte was filled into an aluminum case (external size: $113 \times 150 \times 38 \mathrm{~mm}$ ) and the lid sealed by laser welding. Charge-discharge tests of a $27 \mathrm{Ah} \mathrm{HC} / \mathrm{NaCrO}_{2}$ prismatic cell were conducted at a constant current rate in a thermostatic oven conducted by a computer-controlled charge-discharge unit (ABE 1028-5V, Electrofield Corp).

\section{Results and discussion}

\section{1. $\mathrm{NaCrO}_{2}$ half-cell (coin-type cell)}

A typical charge-discharge curve of a coin-type $\mathrm{Na} / \mathrm{NaCrO}_{2}$ half-cell at $363 \mathrm{~K}$ is shown in Figure 3 (a). The shape of charge-discharge curve is derived from phase transition of $\mathrm{Na}_{1-x} \mathrm{CrO}_{2}(x<0.5)$ during charge-discharge $[6,43]$. In our previous study, phase transitions of $\mathrm{NaCrO}_{2}$ at $363 \mathrm{~K}$ were evaluated by ex-situ XRD measurements [43]. The desodiation of $\mathrm{NaCrO}_{2}$ during charging produces following phase transition: rhombohedral O3 $(x<0.03) \rightarrow$ monoclinic O’3 $(x=0.2) \rightarrow$ monoclinic P'3 $(x>0.34)$. The notations of the phase were designed by Delmas [44]. The potential plateau around $2.9 \mathrm{~V}$ indicates the mixed phase of $\mathrm{O} 3 / \mathrm{O}^{\prime} 3$ or $\mathrm{O}^{\prime} 3 / \mathrm{P}^{\prime} 3$, whereas the potential slope from $3.0 \mathrm{~V}$ to $3.3 \mathrm{~V}$ means the change of interslab distance of $\mathrm{CrO}_{2}$ layers in single phase. The observed reversible capacity is 110 $\mathrm{mAh} \mathrm{g}^{-1}$, and the coulombic efficiency is $>99.9 \%$, which are almost the same numbers as those reported in our previous study [34]. Figures 3 (b) and (c) show discharge curves at 363 and $333 \mathrm{~K}$, respectively, at 
rates of $10-600 \mathrm{~mA}\left(\mathrm{~g}-\mathrm{NaCrO}_{2}\right)^{-1}$. The rate dependence of discharge capacity is also shown in Figure 4. It is seen that the $\mathrm{Na} / \mathrm{NaCrO}_{2}$ cell maintains almost the same discharge capacity of $110 \mathrm{mAh} \mathrm{g}^{-1}$ at discharge rates below $100 \mathrm{~mA} \mathrm{~g}^{-1}$ at both 333 and $363 \mathrm{~K}$. In the case of $363 \mathrm{~K}$, the discharge capacity gradually decreases with the discharge rate, but retains approximately $80 \mathrm{mAh} \mathrm{g}^{-1}$ even at $400 \mathrm{~mA} \mathrm{~g}^{-1}$. In contrast, the discharge capacity markedly decreases at $333 \mathrm{~K}$ as the discharge rate increases over $200 \mathrm{~mA}$ $\mathrm{g}^{-1}$. Specifically, in the discharge curves at $333 \mathrm{~K}$, the voltage of the plateaus drop and its length shortens at values higher than $200 \mathrm{~mA} \mathrm{~g}^{-1}$. These results indicate that the operating temperature has a significant effect on the discharge rate performance. These results suggest that $\mathrm{Na}^{+}$ion insertion into the $\mathrm{CrO}_{2}$ layer of $\mathrm{NaCrO}_{2}$ is decelerated at lower temperatures.

\subsection{Hard carbon half-cell (coin-type cell)}

A typical charge-discharge curve for a $\mathrm{Na} / \mathrm{HC}$ cell at $50 \mathrm{~mA} \mathrm{~g}^{-1}$ at $363 \mathrm{~K}$ is shown in Figure 5 (a). The observed reversible capacity is ca. $270 \mathrm{mAh} \mathrm{g}^{-1}$ and the coulombic efficiency is higher than $99 \%$. The cycle properties of the $\mathrm{Na} / \mathrm{HC}$ cell have already been reported in our previous study [39]. Discharge curves at various discharge rates of $25-1000 \mathrm{~mA} \mathrm{~g}^{-1}$ at 363 and $333 \mathrm{~K}$ are shown in Figures 5 (b) and (c), respectively. The outline shapes of discharge curves do not change even at $750 \mathrm{~mA} \mathrm{~g}^{-1}$ at $333 \mathrm{~K}$ and 1000 $\mathrm{mA} \mathrm{g}^{-1}$ at $363 \mathrm{~K}$. The observed positive shifts of the curves at higher discharge rates $\left(>250 \mathrm{~mA} \mathrm{~g}^{-1}\right)$ are likely due to IR drops, because the value of positive shift is proportional to the increment of discharge rate (current density).

Figure 6 shows the rate dependence of the discharge capacity at 333 and $363 \mathrm{~K}$. The observed discharge capacities at the same discharge rate are almost identical at both temperatures, indicating that the rate of $\mathrm{Na}^{+}$extraction from $\mathrm{HC}$ is not largely affected by temperature under the present experimental conditions. In summary, the HC negative electrode has excellent rate capability in the $\mathrm{Na}[\mathrm{FSA}]-\left[\mathrm{C}_{3} \mathrm{C}_{1}\right.$ pyrr][FSA] ionic liquid at 333 and $363 \mathrm{~K}$. A comparison of Figure 4 with Figure 6 clearly indicates that the $\mathrm{HC}$ negative electrode has a superior rate capability than the $\mathrm{NaCrO}_{2}$ positive electrode, in the present tests.

\subsection{5 mAh $\mathrm{HC} / \mathrm{NaCrO}_{2}$ full cell (coin-type cell)}

Figure 7 (a) shows the charge-discharge curve for a $1.5 \mathrm{mAh} \mathrm{HC} / \mathrm{NaCrO}_{2}$ full cell operating in 
the voltage range of $1.5-3.4 \mathrm{~V}$ at $0.3 \mathrm{~mA}$ and $363 \mathrm{~K}$. The voltage plateaus observed at around $2.9 \mathrm{~V}$ on both the charge and discharge curves are derived from the character of the $\mathrm{NaCrO}_{2}$ positive electrode. The monotonic voltage changes in the region of $1.5-2.7 \mathrm{~V}$ arise from the features of the $\mathrm{HC}$ negative electrode. The average discharge voltage is ca. $2.6 \mathrm{~V}$. The observed cell capacity is $1.53 \mathrm{mAh}$, which corresponds to $102 \mathrm{mAh}\left(\mathrm{g}-\mathrm{NaCrO}_{2}\right)^{-1}$ for the positive electrode and $252 \mathrm{mAh}(\mathrm{g}-\mathrm{HC})^{-1}$ for the negative electrode. Since the reversible capacities observed in the half-cell tests are $110 \mathrm{mAh}\left(\mathrm{g}-\mathrm{NaCrO}_{2}\right)^{-1}$ and $270 \mathrm{mAh}$ $(\mathrm{g}-\mathrm{HC})^{-1}$, the capacity utilizing ratios are calculated as ca. $93 \%$ for the $\mathrm{NaCrO}_{2}$ and $\mathrm{HC}$ electrodes. Discharge curves at discharge rates of $0.3-9.0 \mathrm{~mA}$ (approximately $5 / \mathrm{C}-6 \mathrm{C}$ rate) at 363 and $333 \mathrm{~K}$ are shown in Figures 7 (b) and (c), respectively. Appreciable changes are observed from $9.0 \mathrm{~mA}$ at $363 \mathrm{~K}$ and $3.0 \mathrm{~mA}$ at $333 \mathrm{~K}$. The observed charge-discharge characteristics are consistent with the results of the half-cells. A superior rate capability is achieved when the cell is operated at $363 \mathrm{~K}$.

To check whether the $\mathrm{HC} / \mathrm{NaCrO}_{2}$ full cell works at temperatures lower than $333 \mathrm{~K}$, charge-discharge tests were conducted at $313,298,283$, and $273 \mathrm{~K}$. Figure 8 shows typical discharge curves at $0.3 \mathrm{~mA}$ and $298 \mathrm{~K}$, and $0.15 \mathrm{~mA}$ at $283 \mathrm{~K}$. The discharge capacities are $1.50 \mathrm{mAh}$ at $298 \mathrm{~K}$ and $1.35 \mathrm{mAh}$ at $283 \mathrm{~K}$. This result confirms that the $\mathrm{HC} / \mathrm{NaCrO}_{2}$ full cell is operable at room temperature or even lower than room temperature with moderate discharge rates. Figure 9 shows the rate dependence of the discharge capacity at $273-363 \mathrm{~K}$. The designated capacity of $1.5 \mathrm{mAh}$ is exerted at temperatures higher than $298 \mathrm{~K}$. The rate capability steadily increases as the temperature increases. The highest rate capability is attained at $363 \mathrm{~K}$.

Figure 10 shows the cycle properties of the $1.5 \mathrm{mAh} \mathrm{HC} / \mathrm{NaCrO}_{2}$ full cell at $1.5 \mathrm{~mA}(1 \mathrm{C})$ rate at $333 \mathrm{~K}$ and $363 \mathrm{~K}$. Even for the fully charging and discharging tests, remarkably stable cycleability is obtained. The capacity is maintained up to $90 \%$ of the initial capacity after 1000 cycles. There is almost no difference in the capacity retentions between $333 \mathrm{~K}$ and $363 \mathrm{~K}$. This stable cycleability at $363 \mathrm{~K}$ is an outstanding achievement, considering that conventional LIBs employing organic solvent-based electrolytes cannot be operated at such high temperatures. The long-term cycle stability in the intermediate temperature range is attributed to the high thermal stability of SEI films on HC negative electrodes as well as good thermal stability of the $\mathrm{Na}[\mathrm{FSA}]-\left[\mathrm{C}_{3} \mathrm{C}_{1}\right.$ pyrr][FSA] ionic liquid itself. Table 2 summarizes the coulombic and energy efficiencies for the $\mathrm{HC} / \mathrm{NaCrO}_{2}$ full cell at a rate of $0.3 \mathrm{~mA}$ at 298 , 333, and $363 \mathrm{~K}$. The obtained coulombic efficiencies are higher than $99.7 \%$ for all temperatures. 
Considerably high charge-discharge energy efficiencies are achieved: $96.9 \%$ at $333 \mathrm{~K}$ and $97.5 \%$ at 363

$\mathrm{K}$. These values are comparable with, or better, than those of conventional LIBs at ambient temperature [40-41]. The slight decrease in the energy efficiency at $298 \mathrm{~K}(93.2 \%)$ is caused by the increase in the internal resistance due to lower ionic conductivity.

\subsection{Ah $\mathrm{HC} / \mathrm{NaCrO}_{2}$ full cells (large-sized prismatic cell)}

Based on the results for coin-type cells, large-size prismatic cells having a designed capacity of $27 \mathrm{Ah}$ were fabricated. The weight and volume of the $27 \mathrm{Ah}$ cell were $1.08 \mathrm{~kg}$, and $0.644 \mathrm{~L}$, respectively.

Figure 11 shows the charge-discharge curves for the $27 \mathrm{Ah} \mathrm{HC} / \mathrm{NaCrO}_{2}$ full cell at 298 and 333 $\mathrm{K}$. The observed discharge capacity at a rate of $2.7 \mathrm{~A}$ is $27.3 \mathrm{Ah}$ at $298 \mathrm{~K}$, which is equal to the designed capacity. At $333 \mathrm{~K}$, almost the same charge-discharge behavior is obtained, even at the higher rate of 10 A. The calculated volumetric and gravimetric energy densities of the $27 \mathrm{Ah}$ cell are ca. $125 \mathrm{Wh} \mathrm{L}^{-1}$ and $75 \mathrm{Wh} \mathrm{kg}^{-1}$, respectively. These values are comparable with those for large-scale prismatic LIBs in the early 2000s [42]. It should be noted that the shape of the charge-discharge curve for the $27 \mathrm{Ah}$ cell is almost identical to that of a $1.5 \mathrm{mAh}$ coin-type cell. Thus, it is expected that the performance of a large-sized full cell is well predicted by that of a coin-type cell. Actually, the calculated energy efficiencies at a rate of $5.4 \mathrm{~A}$ are $93.9 \%$ at $298 \mathrm{~K}$ and $96.8 \%$ at $333 \mathrm{~K}$. These values are almost the same as those for coin-type cells shown in Table 2.

Figure 12 shows the rate dependence of discharge capacity for the 27 Ah full cell at 283, 298, 313,333 , and $363 \mathrm{~K}$. Again, the rate capability is comparable with that for the $1.5 \mathrm{mAh}$ coin-type cell. An especially superior rate capability is obtained at 333 and $363 \mathrm{~K}$. On the other hand, the performance is unsatisfactory at $283 \mathrm{~K}$, which is due to the lower conductivity of the ionic liquid. Figure 13 shows the cycleability of the $27 \mathrm{Ah}$ full cell at a rate of $10 \mathrm{~A}$ at $333 \mathrm{~K}$. This is also the fully charging and discharging test done in the same manner as the coin-type cell. The capacity retention after 500 cycles is $87 \%$. Although this value is slightly lower than that of the $1.5 \mathrm{mAh}$ coin-type cell shown in Figure 10, it is the same value as that of large-scaled prismatic LIBs used in the early 2000s [42]. Considering that the $27 \mathrm{Ah}$ cell has been produced by an industrial process similar to that for conventional LIBs, it is safe to say that a large-sized $\mathrm{HC} / \mathrm{Na}[\mathrm{FSA}]-\left[\mathrm{C}_{3} \mathrm{C}_{1}\right.$ pyrr $][\mathrm{FSA}] / \mathrm{NaCrO}_{2}$ cell can show further improvements in energy 
density, power density (rate capability), energy efficiency, and cycleability with improved manufacturing technology.

As described in this section, $\mathrm{HC} / \mathrm{Na}[\mathrm{FSA}]-\left[\mathrm{C}_{3} \mathrm{C}_{1}\right.$ pyrr $][\mathrm{FSA}] / \mathrm{NaCrO}_{2}$ cells exhibit high performance and long cycle life over a wide temperature range including a high temperature of $363 \mathrm{~K}$. Thus, these cells are best expected to be used in new fields where conventional LIBs cannot be used. For example, near heated devices such as engines in hybrid electric vehicles (HEVs), or fuel cells in fuel cell vehicles (FCVs). This is highly beneficial even for electric vehicles (EVs). The temperature controlling system for the EV battery becomes much simpler, and the closest packing of cells can be realized because the upper-limit temperature of the battery is improved by $40-50 \mathrm{~K}$ compared with that in conventional LIBs. In addition, these cells can be used in mid-to-large-sized power storage devices that are operated under hot environments (for example, the tropical and desert regions).

\section{Conclusions}

Sodium ion batteries consisting of an $\mathrm{HC}$ negative electrode, a $\mathrm{NaCrO}_{2}$ positive electrode, and a $\mathrm{Na}[\mathrm{FSA}]-\left[\mathrm{C}_{3} \mathrm{C}_{1}\right.$ pyrr][FSA $]$ ionic liquid have been systematically investigated using coin-type half-cells, coin-type full cells, and large-sized full cells at 273-363 K. First, fundamental charge-discharge characteristics of $\mathrm{NaCrO}_{2}$ and $\mathrm{HC}$ electrodes were presented using coin-type half-cells at 333 and $363 \mathrm{~K}$. Second, a coin-type $1.5 \mathrm{mAh} \mathrm{HC} / \mathrm{NaCrO}_{2}$ full cell was successfully fabricated, giving a specific capacity of $102 \mathrm{mAh}\left(\mathrm{g}-\mathrm{NaCrO}_{2}\right)^{-1}$ and $252 \mathrm{mAh}(\mathrm{g}-\mathrm{HC})^{-1}$ at an operation voltage range of 1.5-3.35 V. Charge-discharge energy efficiencies were as high as $96.9 \%$ at $333 \mathrm{~K}$, and $97.5 \%$ at $363 \mathrm{~K}$. The cell also exhibited a wide operational temperature range of $283-363 \mathrm{~K}$, and excellent cycle performance of $90 \%$ capacity retention after 1000 cycles at $363 \mathrm{~K}$. Finally, a $27 \mathrm{Ah} \mathrm{HC} / \mathrm{NaCrO}_{2}$ full cell was constructed using a mass production process. The calculated volumetric and gravimetric energy densities were $125 \mathrm{Wh} \mathrm{L}^{-1}$ and $75 \mathrm{Wh} \mathrm{kg}^{-1}$, respectively. The energy efficiencies were $93.9 \%$ at $298 \mathrm{~K}$, and $96.8 \%$ at $333 \mathrm{~K}$, as high as those of the coin-type $1.5 \mathrm{mAh}$ full cell. The $27 \mathrm{Ah}$ full cell also showed a wide operational temperature range and a long cycle life of $87 \%$ capacity retention after 500 cycles. The performance of the 27 Ah cell was comparable with that of the $1.5 \mathrm{mAh}$ coin-type cell, demonstrating for the first time the successful fabrication of a large-scale sodium-ion battery using a $\mathrm{Na}[\mathrm{FSA}]-\left[\mathrm{C}_{3} \mathrm{C}_{1}\right.$ pyrr] $[\mathrm{FSA}]$ ionic liquid. 


\section{Acknowledgements}

This study was partly supported by Advanced Low Carbon Technology Research and Development Program (ALCA) of Japan Science and Technology Agency (JST) and the Japanese Ministry of Education Culture, Sports, Science and Technology (MEXT) program "Elements Strategy Initiative to Form Core Research Center" (since 2012). 


\section{References}

1. J. Tollefson, (2008) Car industry: Charging up the future. Nature 456:436-440

2. E. Marris (2008) Energy: Upgranding the grid. Nature 454:570-573

3. M. Winter, R.J. Brodd (2004) What Are Batteries, Fuel Cells, and Supercapacitors? Chem Rev $104: 4245-4269$

4. G.L. Soloveichik (2011) Battery technologies for large-scale stationary energy storage. Annu Rev Chem Biomol Eng 2:503-527

5. N. Yabuuchi, M. Kajiyama, J. Iwatate, H. Nishikawa, S. Hitomi, R. Okuyama, R. Usui, Y. Yamada, S. Komaba (2012) P2-type $\mathrm{Nax}\left[\mathrm{Fe}_{1 / 2} \mathrm{Mn}_{1 / 2}\right] \mathrm{O}_{2}$ made from earth-abundant elements for rechargeable Na batteries. Nat Mater 11:512-517

6. S. Komaba, C. Takei, T. Nakayama, A. Ogata, N. Yabuuchi (2012) Electrochemical intercalation activity of layered $\mathrm{NaCrO}_{2}$ vs. $\mathrm{LiCrO}_{2}$. Electrochem Commun 12:355-358

7. S. Komaba, N. Yabuuchi, T. Nakayama, A. Ogata, T. Ishikawa, I. Nakai (2012) Study on the Reversible Electrode Reaction of $\mathrm{Na}_{1-\mathrm{x}} \mathrm{Ni}_{0.5} \mathrm{Mn}_{0.5} \mathrm{O}_{2}$ for a Rechargeable Sodium-Ion Battery. Inorg Chem 51:6211-6220

8. J. Billaud, G. Singh, A.R. Armstrong, E. Gonzalo, V. Roddatis, M. Armand, T. Rojob, P.G. Bruce (2014) $\mathrm{Na}_{0.67} \mathrm{Mn}_{1-\mathrm{x}} \mathrm{Mg}_{\mathrm{x}} \mathrm{O}_{2}(0 \leq \mathrm{x} \leq 0.2)$ : a high capacity cathode for sodium-ion batteries. Energy Environ Sci 7:1387-1391

9. J.J. Ding, Y.N. Zhou, Q. Sun, Z.W. Fu (2012) Cycle performance improvement of $\mathrm{NaCrO}_{2}$ cathode by carbon coating for sodium ion batteries. Electrochem Commun 22:85-88

10. N. Yabuuchi, H. Yoshida, S. Komaba (2012) Crystal Structures and Electrode Performance of Alpha- $\mathrm{NaFeO}_{2}$ for Rechargeable Sodium Batteries. Electrochemistry 80:716-719

11. P. Vassilaras, X.H. Ma, X. Li, G. Ceder (2013) Electrochemical Properties of Monoclinic $\mathrm{NaNiO}_{2}$. J Electrochem Soc 160:A207-A211

12. M. Sathiya, K. Hemalatha, K. Ramesha, J.M. Tarascon, A.S. Prakash (2012) Synthesis, Structure, and Electrochemical Properties of the Layered Sodium Insertion Cathode Material: $\mathrm{NaNi}_{1 / 3} \mathrm{Mn}_{1 / 3} \mathrm{Co}_{1 / 3} \mathrm{O}_{2}$. Chem Mater 24:1846-1853

13. H. Yoshida, N. Yabuuchi, S. Komaba (2013) $\mathrm{NaFe}_{0.5} \mathrm{Co}_{0.5} \mathrm{O}_{2}$ as high energy and power positive electrode for $\mathrm{Na}-\mathrm{ion}$ batteries. Electrochem Commun 34:60-63 
14. B.M. de Boisse, D. Carlier, M. Guignard, C. Delmas (2013) Structural and Electrochemical Characterizations of $\mathrm{P} 2$ and New $\mathrm{O} 3-\mathrm{Na}_{\mathrm{x}} \mathrm{Mn}_{1-\mathrm{y}} \mathrm{Fe}_{\mathrm{y}} \mathrm{O}_{2}$ Phases Prepared by Auto-Combustion Synthesis for Na-Ion Batteries. J Electrochem Soc 160:A569-A574

15. J. Zhao, J. Xu, D.H. Lee, N. Dimov, Y.S. Meng, S. Okada (2014) Electrochemical and thermal properties of P2-type $\mathrm{Na}_{2 / 3} \mathrm{Fe}_{1 / 3} \mathrm{Mn}_{2 / 3} \mathrm{O}_{2}$ for $\mathrm{Na}$-ion batteries. J Power Sources 264:235-239

16. J.M. Tarascon (2010) Is lithium the new gold? Nat Chem 2:510

17. W. Tahil (2007) The Trouble With Lithium. http://go.nature.com/jhDqLH. Accessed 1 September 2015

18. W. Tahil (2008) The Trouble With Lithium 2. http://go.nature.com/AWITRo. Accessed 1 September 2015

19. Y.F.Y. Yao, J.T. Kummer (1967) Ion exchange properties of and rates of ionic diffusion in beta-alumina. J Inorg Nucl Chem 29:2453-2475

20. J.L. Sudworth (1984) The sodium/sulphur battery. J Power Sources 11:143-154

21. J. Coetzer (1986) A new high energy density battery system. J Power Sources 18:377-380

22. C.H. Dustmann (2004) Advances in ZEBRA batteries. J Power Sources 127:85-92

23. K.B. Hueso, M. Armand, T. Rojo (2010) High temperature sodium batteries: status, challenges and future trends. Energy Environ Sci 6:734-749

24. X.C. Lu, G.G. Xia, J.P. Lemmon, Z.G. Yang (2010) Advanced materials for sodium-beta alumina batteries: Status, challenges and perspectives. J Power Sources 195:2431-2442

25. K. Kubota, N. Yabuuchi, H. Yoshida, M. Dahbi, S. Komaba (2014) Layered oxides as positive electrode materials for Na-ion batteries. MRS Bulletin 39:416-422

26. H. Pan, Y. S. Hu, L. Chen (2013) Room-temperature stationary sodium-ion batteries for large-scale electric energy storage. Energy Environ Sci 6:2338-2360

27. N. Yabuuchi, K. Kubota, M. Dahbi, S. Komaba (2014) Research Development on Sodium-Ion Batteries. Chem Rev 114:11636-11682

28. K. Kubota, T. Nohira, T. Goto, R. Hagiwara (2008) Novel inorganic ionic liquids possessing low melting temperatures and wide electrochemical windows: Binary mixtures of alkali bis(fluorosulfonyl)amides. Electrochem Commun 10:1886-1888

29. K. Kubota, T. Nohira, R. Hagiwara (2010) Thermal Properties of Alkali Bis(fluorosulfonyl)amides 
and Their Binary Mixtures. J Chem Eng Data 55:3142-3146

30. K. Kubota, T. Nohira, R. Hagiwara (2012) New inorganic ionic liquids possessing low melting temperatures and wide electrochemical windows: Ternary mixtures of alkali bis(fluorosulfonyl)amides. Electrochim Acta 66:320-324

31. R. Hagiwara, K. Tamaki, K. Kubota, T. Goto, T. Nohira (2008) Thermal properties of mixed alkali bis(trifluoromethylsulfonyl)amides. J Chem Eng Data 53:355-358

32. T. Nohira, T. Ishibashi, R. Hagiwara (2012) Properties of an intermediate temperature ionic liquid NaTFSA-CsTFSA and charge-discharge properties of $\mathrm{NaCrO}_{2}$ positive electrode at $423 \mathrm{~K}$ for a sodium secondary battery. J Power Sources 205:506-509

33. A. Fukunaga, T. Nohira, Y. Kozawa, R. Hagiwara, S. Sakai, K. Nitta, S. Inazawa (2012) Intermediate-temperature ionic liquid NaFSA-KFSA and its application to sodium secondary batteries. J Power Sources 209:52-56

34. C.S. Ding, T. Nohira, K. Kuroda, R. Hagiwara, A. Fukunaga, S. Sakai, K. Nitta, S. Inazawa (2013) $\mathrm{NaFSA}-\mathrm{C}_{1} \mathrm{C}_{3}$ pyrFSA ionic liquids for sodium secondary battery operating over a wide temperature range. J Power Sources 238:296-300

35. X. Xia, J.R. Dahn (2012) $\mathrm{NaCrO}_{2}$ is a Fundamentally Safe Positive Electrode Material for Sodium-Ion Batteries with Liquid Electrolytes. Electrochem Solid-State Lett 15:A1-A4

36. M. Dahbi, T. Nakano, N. Yabuuchi, T. Ishikawa, K. Kubota, M. Fukunishi, S. Shibahara, J.Y. Son, Y.T. Cui, H. Oji, S. Komaba (2014) Sodium carboxymethyl cellulose as a potential binder for hard-carbon negative electrodes in sodium-ion batteries. Electrochem Comm 44:66-69

37. K. Gotoh, T. Ishikawa, S. Shimadzu, N. Yabuuchi, S. Komaba, K. Takeda, A. Goto, K. Deguchi, S. Ohki, K. Hashi, T. Shimizu, H. Ishida (2013) NMR study for electrochemically inserted Na in hard carbon electrode of sodium ion battery. J Power Sources 225:137-140

38. S. Komaba, W. Murata, T. Ishikawa, N. Yabuuchi, T. Ozeki, T. Nakayama, A. Ogata, K. Gotoh, K. Fujiwara (2011) Electrochemical $\mathrm{Na}$ insertion and solid electrolyte interphase for hard-carbon electrodes and application to Na-ion batteries. Adv Funct Mater 21:3859-3867

39. A. Fukunaga, T. Nohira, R. Hagiwara, K. Numata, E. Itani, S. Sakai, K. Nitta, S. Inazawa (2014) A safe and high-rate negative electrode for sodium-ion batteries: Hard carbon in NaFSA- $\mathrm{C}_{1} \mathrm{C}_{3}$ pyrFSA ionic liquid at 363 K. J Power Sources 246:387-391 
40. C.J. Rydh, B.A. Sandén (2005) Energy analysis of batteries in photovoltaic systems. Part II: Energy return factors and overall battery efficiencies. Energ Convers Manag 46:1980-2000

41. H. Chen, T.N. Cong, W. Yang, C. Tan, Y. Li, Y. Ding (2009) Progress in electrical energy storage system: A critical review. Prog Nat Sci 19:291-312

42. T. Iguchi, K. Okamoto, J. Kuratomi, K. Ohkawa, K. Kohno, S. Izuchi (2004) Development of Lithium-Ion Battery "EX25A" with New Positive Active Material of $\mathrm{LiCo}_{\mathrm{x}} \mathrm{Mn}_{\mathrm{y}} \mathrm{Ni}_{\mathrm{z}} \mathrm{O}_{2}(\mathrm{x}+\mathrm{y}+\mathrm{z}=1)$ : GS Yuasa Technical Report 1:25-31

43. C.Y. Chen, K. Matsumoto, T. Nohira, R. Hagiwara, A. Fukunaga, S. Sakai, K. Nitta, S. Inazawa (2013) Electrochemical and structural investigation of $\mathrm{NaCrO}_{2}$ as a positive electrode for sodium secondary battery using inorganic ionic liquid NaFSA-KFSA: J Power Sources 237:52-57

44. C. Delmas, C. Fouassier, P. Hagenmuller (1980) Structural classification and properties of layered oxides: Physica B+C 99:81-85 


\section{Tables}

Table 1 Charge and discharge conditions for $\mathrm{Na} / \mathrm{NaCrO}_{2}, \mathrm{Na} / \mathrm{HC}$, and $\mathrm{HC} / \mathrm{NaCrO}_{2}$ cells.

\begin{tabular}{llll} 
Cell & Charge rate & Discharge rate & Cut-off voltages \\
\hline $\mathrm{Na} / \mathrm{NaCrO}_{2}$ & $20 \mathrm{~mA}\left(\mathrm{~g}-\mathrm{NaCrO}_{2}\right)^{-1}$ & $20-600 \mathrm{~mA}(\mathrm{~g}-\mathrm{NaCrO})^{-1}$ & 2.5 and $3.5 \mathrm{~V}$ \\
\hdashline $\mathrm{Na} / \mathrm{HC}$ & $25 \mathrm{~mA}(\mathrm{~g}-\mathrm{HC})^{-1}$ & $25-1000 \mathrm{~mA}(\mathrm{~g}-\mathrm{HC})^{-1}$ & 0.005 and $1.2 \mathrm{~V}$ \\
\hdashline $\mathrm{HC}^{\mathrm{N} / \mathrm{NaCrO}_{2}}$ & $20-100 \mathrm{~mA}\left(\mathrm{~g}-\mathrm{NaCrO}_{2}\right)^{-1}$ & $10-600 \mathrm{~mA}\left(\mathrm{~g}-\mathrm{NaCrO}_{2}\right)^{-1}$ & 1.5 and $3.35 \mathrm{~V}$
\end{tabular}


Table 2 Coulombic and energy efficiencies for a $1.5 \mathrm{mAh} \mathrm{HC/Na[FSA}]-\left[\mathrm{C}_{3} \mathrm{C}_{1}\right.$ pyrr $][\mathrm{FSA}] / \mathrm{NaCrO}_{2}$ full cell. Operating temperatures: 298, 333, and $363 \mathrm{~K}$. Charge-discharge rate: $0.3 \mathrm{~mA}$.

\begin{tabular}{lll} 
Operating temperature & Coulombic efficiency & Energy efficiency \\
\hline $363 \mathrm{~K}$ & $99.85 \%$ & $97.5 \%$ \\
\hline $333 \mathrm{~K}$ & $99.84 \%$ & $96.9 \%$ \\
\hline $298 \mathrm{~K}$ & $99.78 \%$ & $93.2 \%$
\end{tabular}




\section{Figure captions}

Figure $1 \quad$ XRD pattern of obtained $\mathrm{NaCrO}_{2}$ powder.

Figure 2 Appearance of a $27 \mathrm{Ah} \mathrm{HC} / \mathrm{Na}[\mathrm{FSA}]-\left[\mathrm{C}_{3} \mathrm{C}_{1}\right.$ pyrr $][\mathrm{FSA}] / \mathrm{NaCrO}_{2}$ prismatic cell. External size: $113 \times 150 \times 38 \mathrm{~mm}$. Weight: $1.08 \mathrm{~kg}$.

Figure 3 (a) A charge-discharge curve for a $\mathrm{Na} / \mathrm{Na}[\mathrm{FSA}]-\left[\mathrm{C}_{3} \mathrm{C}_{1}\right.$ pyrr $][\mathrm{FSA}] / \mathrm{NaCrO}_{2}$ cell at $363 \mathrm{~K}$. Charge-discharge rate: $20 \mathrm{~mA}\left(\mathrm{~g}-\mathrm{NaCrO}_{2}\right)^{-1}$. (b) Discharge curves at $363 \mathrm{~K}$ and (c) discharge curves at $333 \mathrm{~K}$. Charge rate: $20 \mathrm{~mA}\left(\mathrm{~g}-\mathrm{NaCrO}_{2}\right)^{-1}$. Discharge rate: $10-600 \mathrm{~mA}\left(\mathrm{~g}-\mathrm{NaCrO}_{2}\right)^{-1}$. Cut-off voltages: $2.5 \mathrm{~V}$ and $3.5 \mathrm{~V}$.

Figure 4 Rate dependence of discharge capacity for a $\mathrm{Na} / \mathrm{Na}[\mathrm{FSA}]-\left[\mathrm{C}_{3} \mathrm{C}_{1}\right.$ pyrr $][\mathrm{FSA}] / \mathrm{NaCrO}_{2}$ cell. Charge rate: $20 \mathrm{~mA}\left(\mathrm{~g}-\mathrm{NaCrO}_{2}\right)^{-1}$, discharge rate: $10-600 \mathrm{~mA}\left(\mathrm{~g}-\mathrm{NaCrO}_{2}\right)^{-1}$. Operation temperature: 333 and $363 \mathrm{~K}$.

Figure 5 (a) A charge-discharge curve for a $\mathrm{Na} / \mathrm{Na}[\mathrm{FSA}]-\left[\mathrm{C}_{3} \mathrm{C}_{1}\right.$ pyrr] $\left.] \mathrm{FSA}\right] / \mathrm{HC}$ cell at $363 \mathrm{~K}$. Charge-discharge rate: $50 \mathrm{~mA}(\mathrm{~g}-\mathrm{HC})^{-1}$. (b) Discharge curves at $363 \mathrm{~K}$ and (c) discharge curves at $333 \mathrm{~K}$. Charge rate: $50 \mathrm{~mA}(\mathrm{~g}-\mathrm{HC})^{-1}$. Discharge rate: $25-1000 \mathrm{~mA}(\mathrm{~g}-\mathrm{HC})^{-1}$. Cut ${ }^{-}$off voltages: $0.005 \mathrm{~V}$ and 1.2 V.

Figure 6 Rate dependence of discharge capacity for a $\mathrm{Na} / \mathrm{Na}[\mathrm{FSA}]-\left[\mathrm{C}_{3} \mathrm{C}_{1}\right.$ pyrr $][\mathrm{FSA}] / \mathrm{HC}$ cell. Charge rate: $50 \mathrm{~mA}(\mathrm{~g}-\mathrm{HC})^{-1}$, discharge rate: $25-1000 \mathrm{~mA}(\mathrm{~g}-\mathrm{HC})^{-1}$. Operation temperature: 363 and $333 \mathrm{~K}$

Figure 7

(a) A charge-discharge curve for a $1.5 \mathrm{mAh} \mathrm{HC/Na[FSA}]-\left[\mathrm{C}_{3} \mathrm{C}_{1}\right.$ pyrr $][\mathrm{FSA}] / \mathrm{NaCrO}_{2}$ full cell at $363 \mathrm{~K}$. Charge-discharge rate: $0.3 \mathrm{~mA}$. (b) Discharge curves at $363 \mathrm{~K}$, and (c) discharge curves at $333 \mathrm{~K}$. Charge rate: $0.3 \mathrm{~mA}$. Discharge rate: $0.3-9.0 \mathrm{~mA}$. Cut ${ }^{-}$off voltages: $1.5 \mathrm{~V}$ and $3.4 \mathrm{~V}$.

Figure 8 Discharge curves for a $1.5 \mathrm{mAh} \mathrm{HC} / \mathrm{Na}[\mathrm{FSA}]-\left[\mathrm{C}_{3} \mathrm{C}_{1}\right.$ pyrr] $[\mathrm{FSA}] / \mathrm{NaCrO}_{2}$ full cell at 298 and $283 \mathrm{~K}$. Charge condition: $0.3 \mathrm{~mA} \mathrm{CC}-\mathrm{CV}$ (to $0.075 \mathrm{~mA}$ ) at $298 \mathrm{~K}$. Discharge rate: $0.3 \mathrm{~mA}$ (298 $\mathrm{K})$ and $0.15 \mathrm{~mA}(283 \mathrm{~K})$. Cut-off voltages: $1.5 \mathrm{~V}$ and $3.35 \mathrm{~V}$.

Figure 9 Rate dependence of the discharge capacity for a 1.5 mAh $\mathrm{HC} / \mathrm{Na}[\mathrm{FSA}]-\left[\mathrm{C}_{3} \mathrm{C}_{1}\right.$ pyrr] $[\mathrm{FSA}] / \mathrm{NaCrO}_{2}$ full cell. Charge condition: $0.3 \mathrm{~mA} \mathrm{CC}(313-363 \mathrm{~K})$ and $0.3 \mathrm{~mA}$ $\mathrm{CC}-\mathrm{CV}$ (to $0.075 \mathrm{~mA}$ ) at $298 \mathrm{~K}(273-298 \mathrm{~K})$. Discharge rate: 0.15-9.0 mA. Operation temperature: 273-363 K. 
Figure 10 Cycle property for a $\mathrm{HC} / \mathrm{Na}[\mathrm{FSA}]-\left[\mathrm{C}_{3} \mathrm{C}_{1}\right.$ pyrr $][\mathrm{FSA}] / \mathrm{NaCrO}_{2}$ full cell. Charge-discharge rate: $1.5 \mathrm{~mA}$. Operation temperature: $363 \mathrm{~K}$ and $333 \mathrm{~K}$. Cut-off voltages: $1.5 \mathrm{~V}$ and $3.35 \mathrm{~V}$

Figure 11 Charge-discharge curves for a $27 \mathrm{Ah} \mathrm{HC/Na[FSA}]-\left[\mathrm{C}_{3} \mathrm{C}_{1}\right.$ pyrr $][\mathrm{FSA}] / \mathrm{NaCrO}_{2}$ full cell at 298 and $333 \mathrm{~K}$. Charge-discharge rate: $2.7 \mathrm{~A}(298 \mathrm{~K})$ and $10 \mathrm{~A}(333 \mathrm{~K})$. Cut-off voltages: $1.5 \mathrm{~V}$ and $3.35 \mathrm{~V}$.

Figure 12 Rate dependence of discharge capacity for a 27 Ah $\mathrm{HC} / \mathrm{Na}[\mathrm{FSA}]-\left[\mathrm{C}_{3} \mathrm{C}_{1}\right.$ pyrr][FSA $] / \mathrm{NaCrO}_{2}$ full cell. Charge rate: $2.7 \mathrm{~A}(283-293 \mathrm{~K})$ and $5.4 \mathrm{~A}(313-363 \mathrm{~K})$, discharge rate: $2.7-81 \mathrm{~A}$. Operation temperature: $283-363 \mathrm{~K}$.

Figure 13 Cycle property for a $27 \mathrm{Ah} \mathrm{HC} / \mathrm{Na}[\mathrm{FSA}]-\left[\mathrm{C}_{3} \mathrm{C}_{1}\right.$ pyrr $][\mathrm{FSA}] / \mathrm{NaCrO}_{2}$ full cell. Charge-discharge rate: $10 \mathrm{~A}$. Operation temperature: $333 \mathrm{~K}$. Cut-off voltages: $1.5 \mathrm{~V}$ and $3.35 \mathrm{~V}$. 


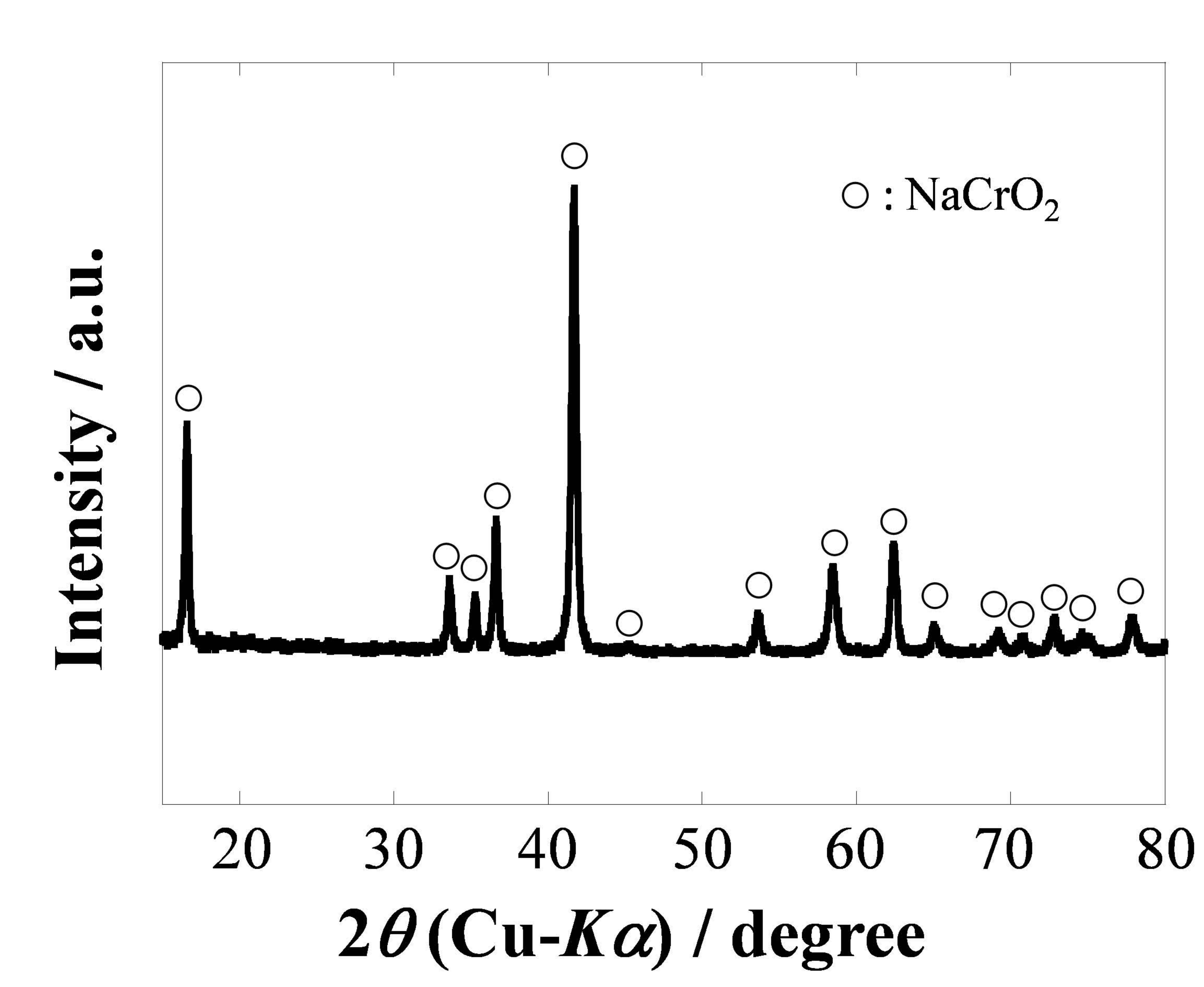

$$
\begin{array}{ccccccc}
20 & 30 & 40 & 50 & 60 & 70 & 80 \\
& \boldsymbol{2} \boldsymbol{\theta}(\mathbf{C u}-\boldsymbol{K} \boldsymbol{\alpha}) / \text { degree } & &
\end{array}
$$



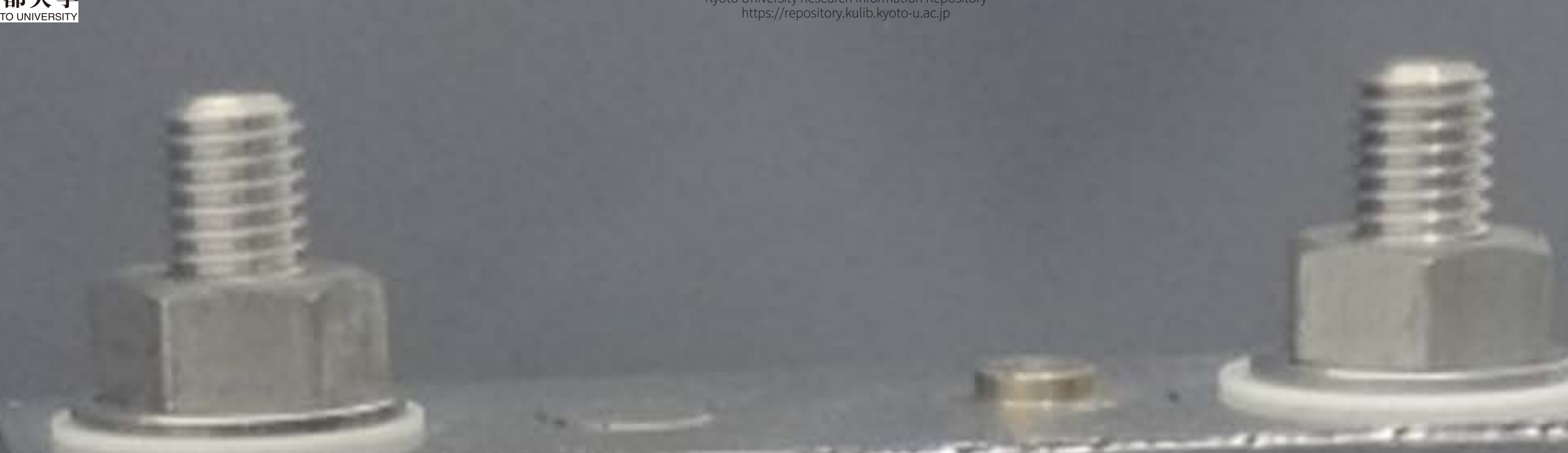

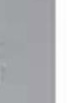

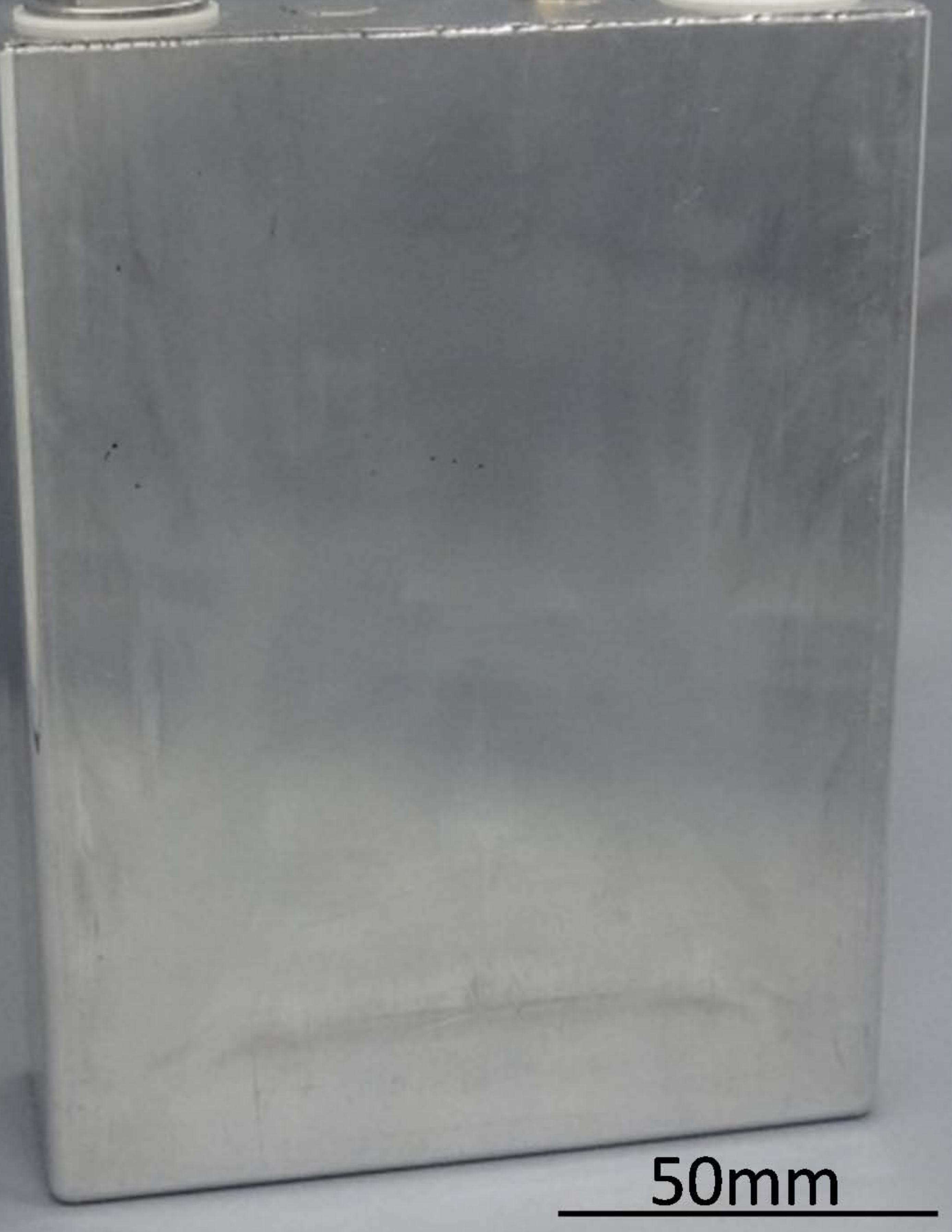



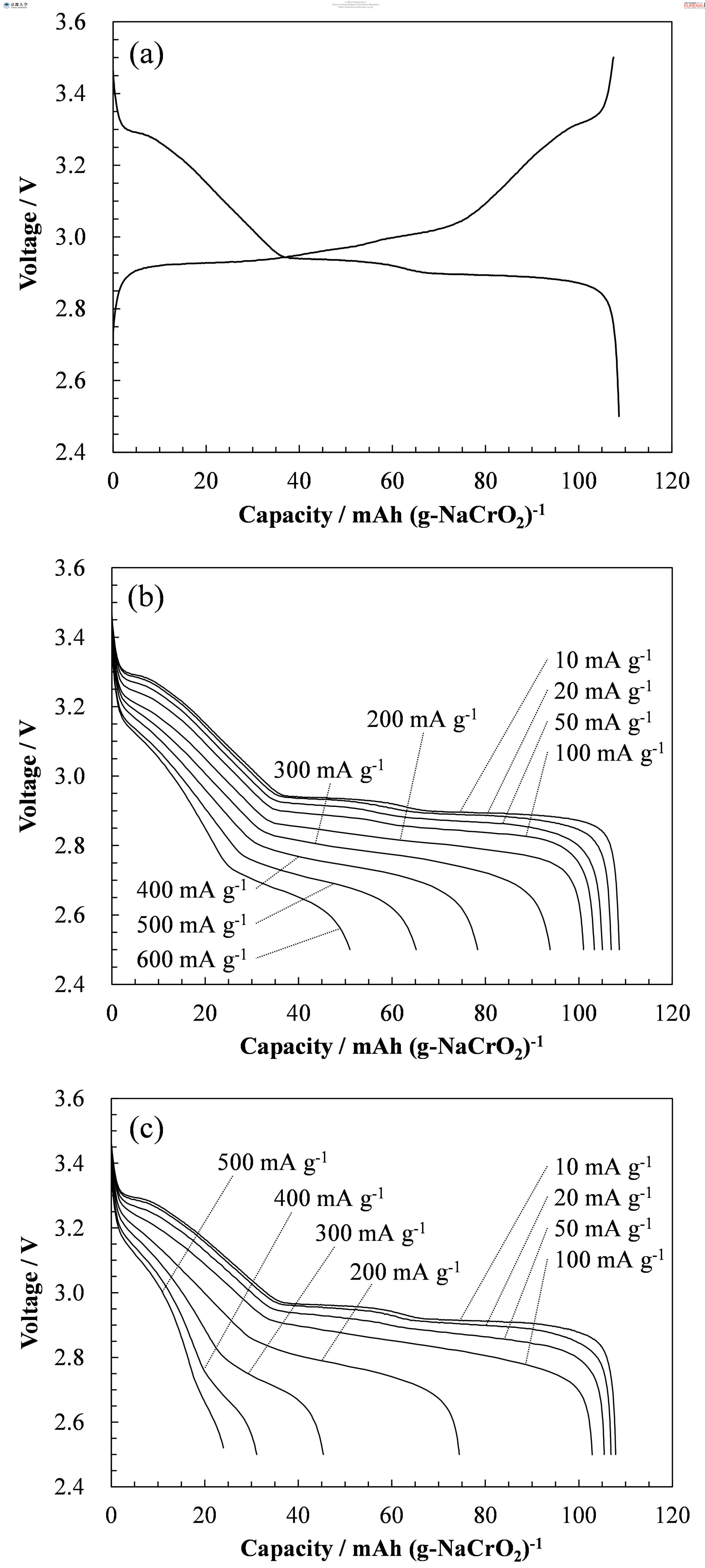


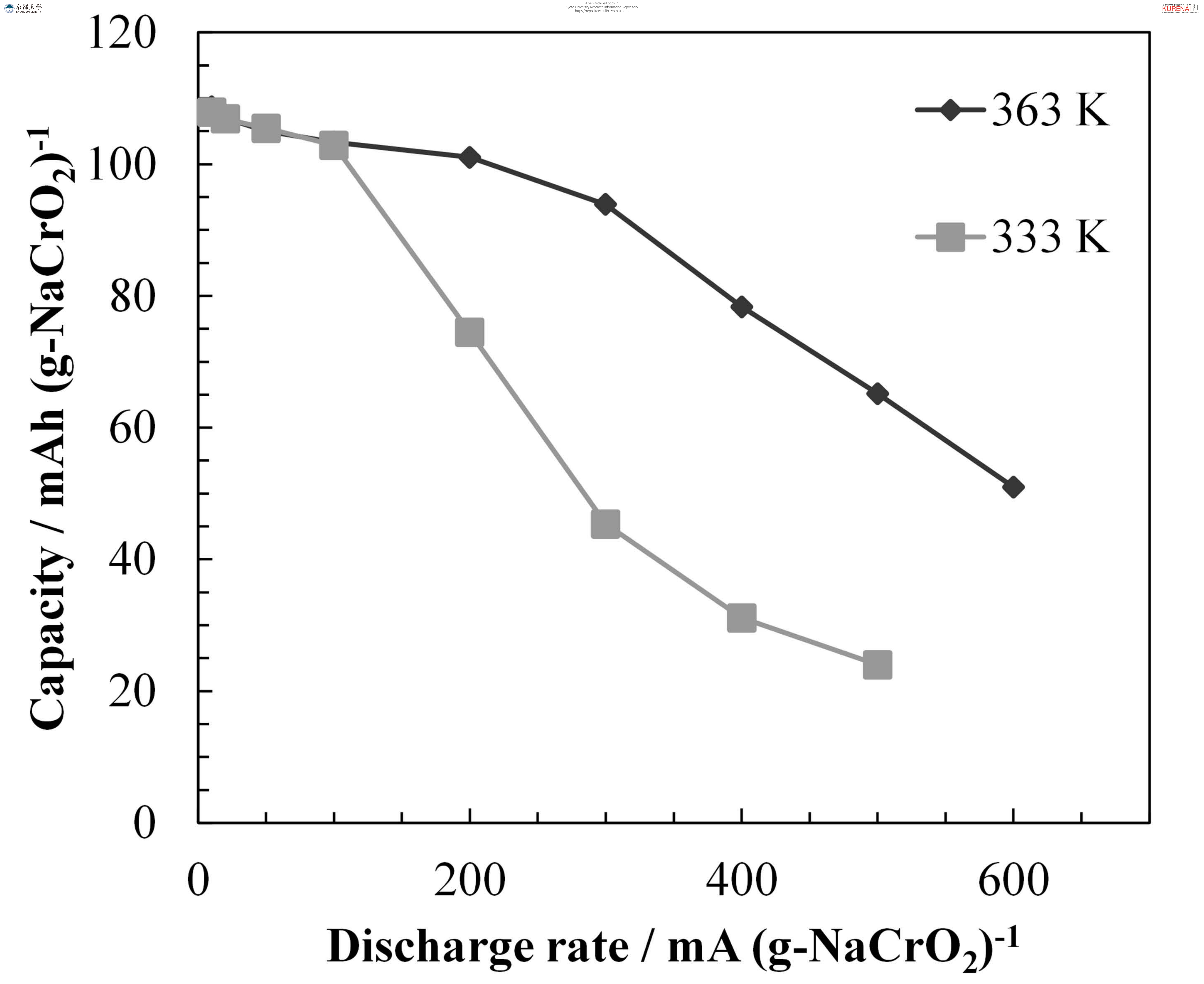



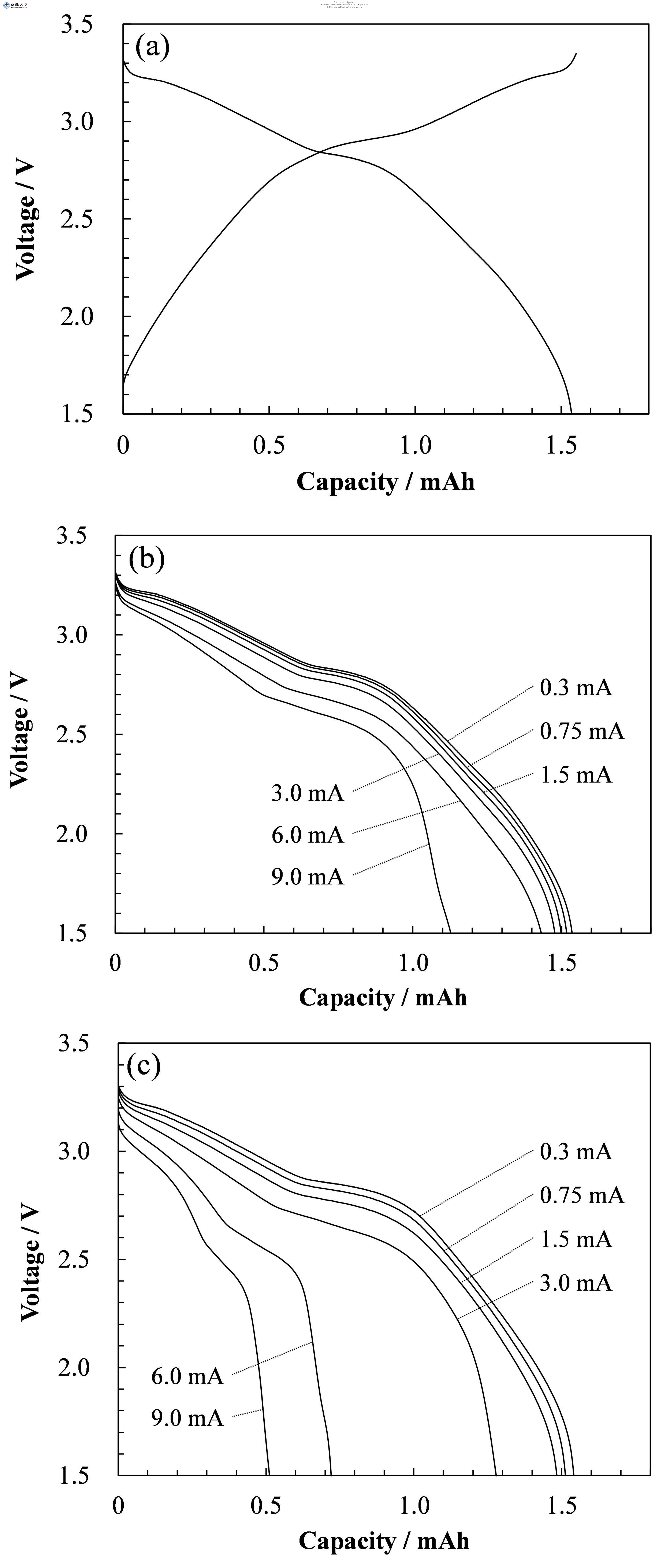


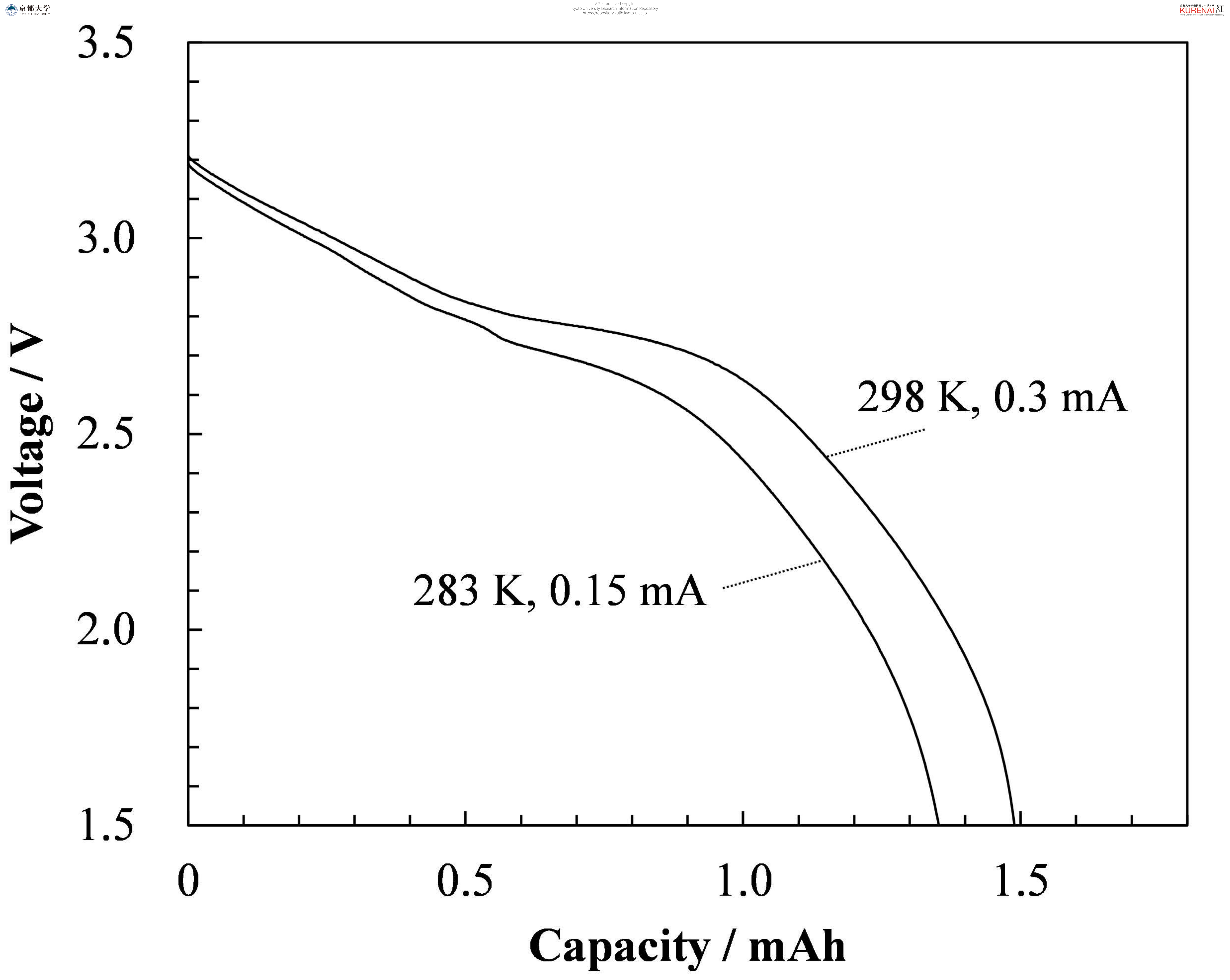




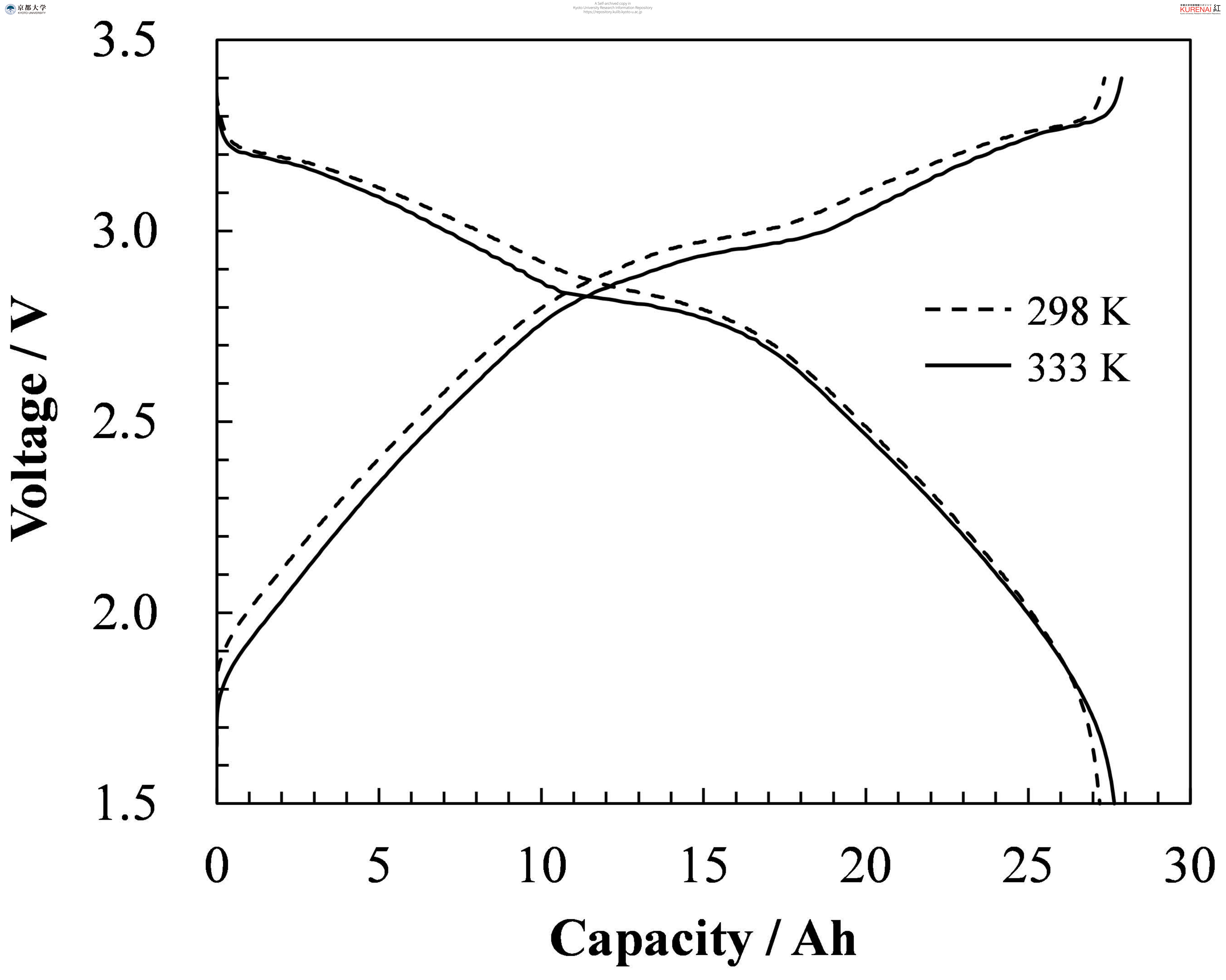




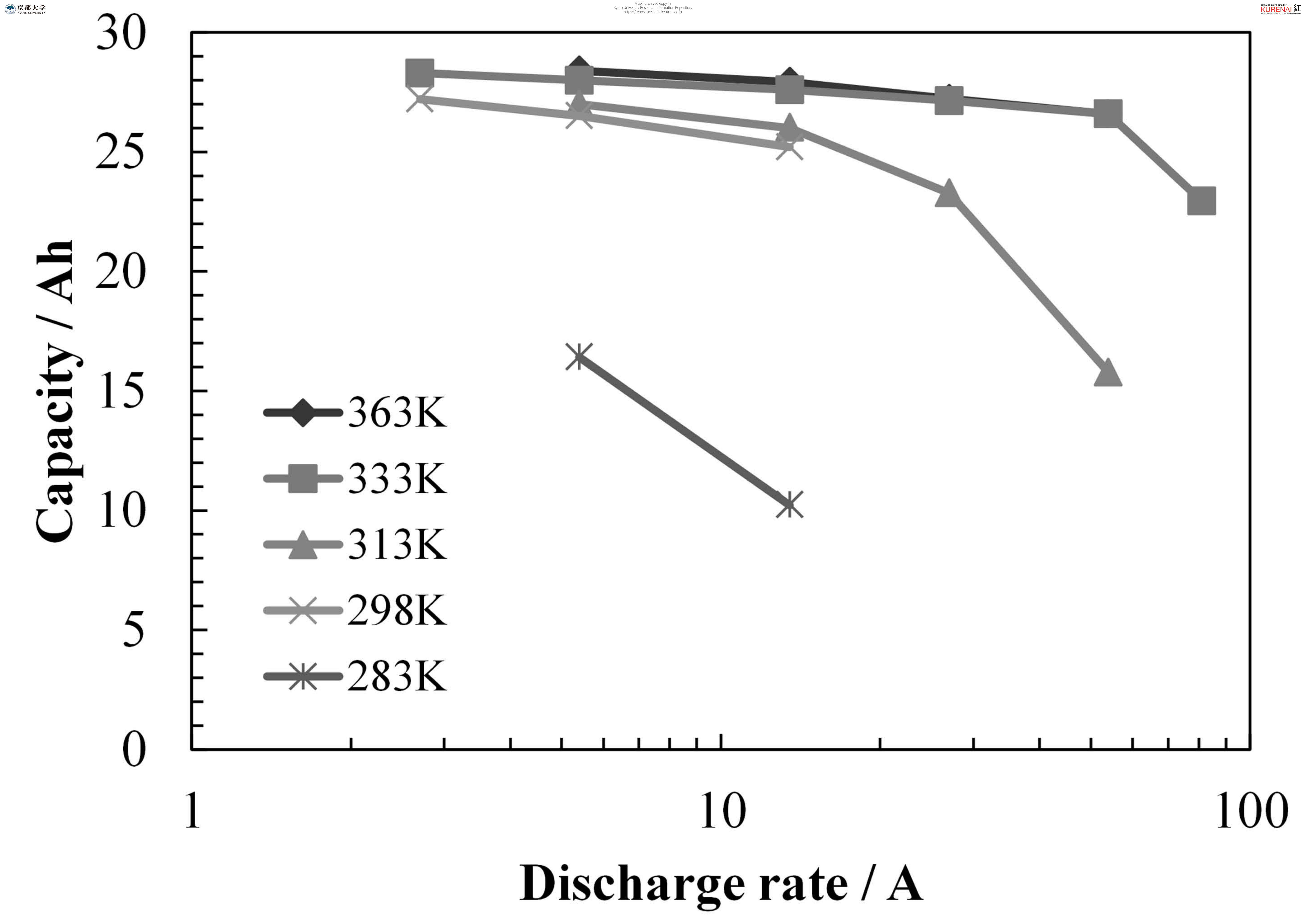




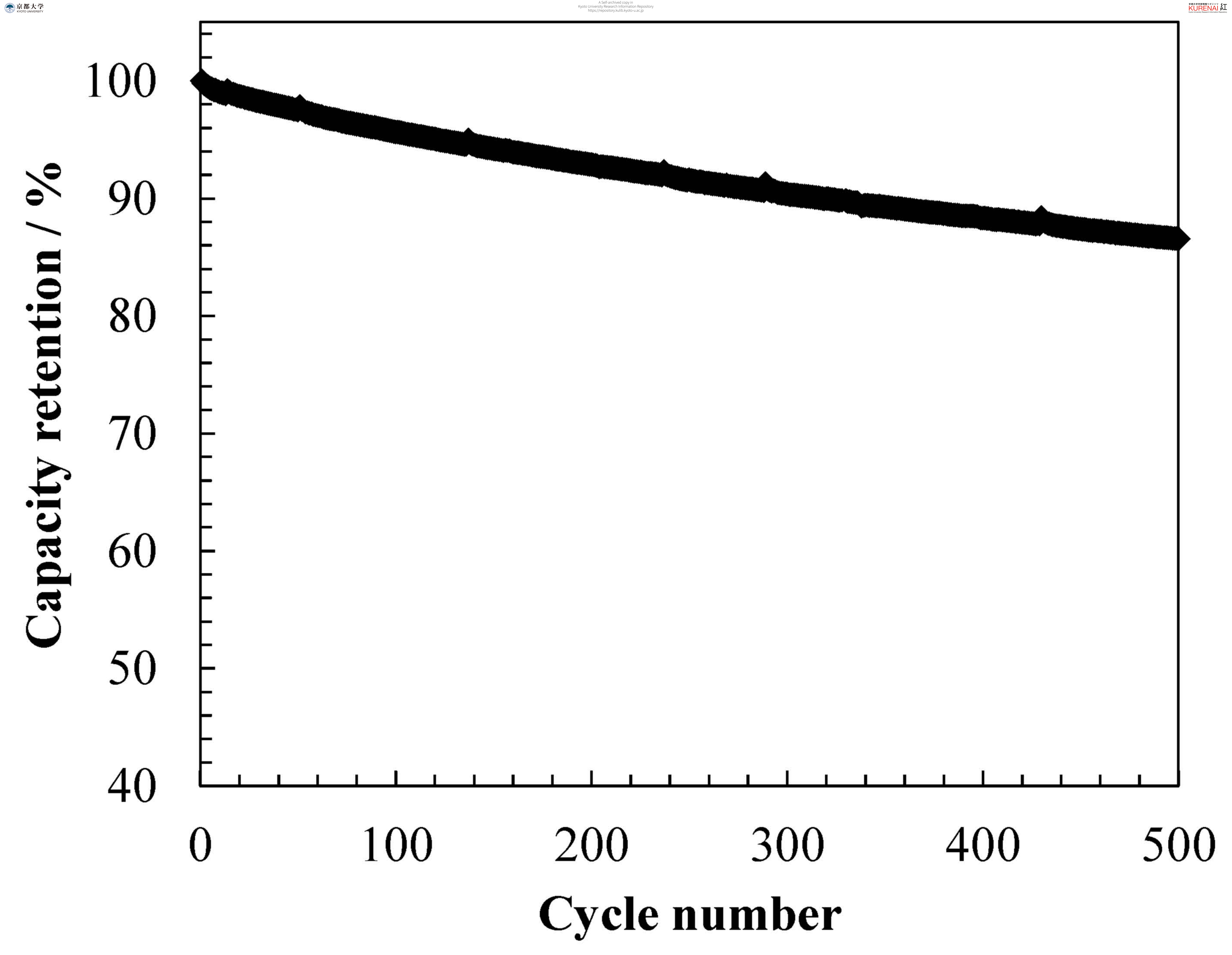

